\title{
Optimal Use of Virtual Learning Environments (Moodle) in Healthcare and Adult Learning through the Essential Understanding of the Who, What and How of E-learning - Use of ADDIE Model
}

\author{
Ebru Heyberi-Tenekeci ${ }^{1 *}$ \\ ${ }^{1}$ International Final University, Faculty of Educational Sciences, Kyrenia, North Cyprus (ORCID: 0000-0002-7870-0002)
}

(This publication has been presented orally at HORA 2019 congress.)

(First received 1 August 2019 and in final form 24 October 2019)

(DOI: 10.31590/ejosat.637585)

ATIF/REFERENCE: Heyberi-Tenekeci, E. (2019). Optimal Use of Virtual Learning Environments (Moodle) in Healthcare and Adult Learning through the Essential Understanding of the Who, What and How of E-learning - Use of ADDIE Model. European Journal of Science and Technology, (Special Issue), 109-118.

\begin{abstract}
The utilisation of blended learning in adult training and education has become popular over the past few decades. The trainers, educators have made excessive steps to use such technologies, with Moodle often being a platform of choice to meet the needs of adult learners in healthcare (hospitals), academia and other organisations by designing trainings/courses using belended learning approach. Within universities, virtual learning environments, very often the Moodle platform has become a most popular form of elearning and blended learning. However, compare to its application within other areas of education, there is a limited available range from which can be selected the best way of implementation e-learning in adult education especially in healthcare sector in hospital environment. Educators in academia and e-learning leads in hospitals first, need to understand the mechanism by which who, what and how of e-learning will be delivered. Amongst a variety of researches regarding an ADDIE model as and instructional design, none considered its applicability in the healthcare and adult education. This paper, therefore, provided a guide of useage of the ADDIE Model in the heltcare settings to Design Basic Life Support (BLS) Training for Healthcare Professionals.
\end{abstract}

Keywords: VLE, Moodle, e-learning, e-ADDIE Model

\section{Hastene Çalışanları ve Yetişkinlerin Öğreniminde Sanal Öğrenme Ortamlarının (Moodle) Optimal Kullanımı: Kimin, Neyin ve Nasıl Öğrenileceğinin Temel Anlayıșı ile ADDIE Modelinin Kullanımı}

\begin{abstract}
$\ddot{O} z$
E-öğrenmenin yetişkinlerin eğitimi ve eğitim programlarında kullanımı son birkaç on yılda popüler hale gelmiştir. Eğitimciler ve eöğrenme liderleri, bu tür teknolojilerinin kullanımı için büyük adımlar attmıştır. Moodle, çoğu zaman sağlık hizmetlerinde (hastanelerde), akademilerde ve diğer organizasyonlarda yetişkin öğrencilerin ihtiyaçlarını karşılamak için tercih edilen bir platform haline gelmiştir. Üniversiteler içerisinde sanal öğrenme ortamları, sıklıkla Moodle platformu en popüler e-öğrenme modeli haline gelmiştir.Bununla birlikte, diğer eğitim alanlarındaki uygulamalarıyla karşılaştırıldığında, özellikle hastane ortamında, sağlık sektöründe yetişkin eğitiminde e-öğrenmenin en iyi uygulama yolu seçilebilecek sınırlı bir alan vardır. Akademilerdeki ve eöğrenimdeki eğitimcilerin önce hastanelerde öncülük etmesi, e-öğrenmenin kim, ne ve nasıl sağlanacağı mekanizmasını anlamas gerekir. Bir ADDIE modeli öğretim tasarımı ile ilgili çeşitli araştırmalar arasında hiçbiri, sağlık bakımı ve yetişkin eğitiminde uygulanabilirliğini düşünmemiştir. Bu nedenle, bu yazıda, ADDIE Modelinin sağlık sektörü ortamlarında Sağlık Profesyonelleri için Tasarım Temel Yaşam Desteği (BLS) Eğitimine yönelik kullanım kılavuzuna yer verilmiş̧tir.
\end{abstract}

Anahtar Kelimeler: Sanal Öğrenme Ortamı, Moodle, E-öğrenme, ADDIE Modeli.

\footnotetext{
* Associate Prof. Dr. Ebru Heyberi-Tenekeci: International Final University, Faculty of Educational Sciences, Kyrenia, North Cyprus (ORCID: 00000002-7870-0002), ebru-tenekeci@hotmail.com
} 


\section{Introduction}

The The rapid growth and spread of information and communication technology (ICT) over the past two decades has substantially changed numerous aspects of daily life for many societies. It is therefore unsurprising that such technologies would also find their way into making changes within various aspects of education and training. A great deal of consideration has been given to how computers, other electronic devices and the Internet can assist and improve educational processes [1]. Although forms of computer assisted learning have been used for 30 or more years, teachers, lecturers and trainers can still find themselves faced with situations concerning relatively basic issues of how it should be implemented. Though many terms are frequently in use describing the application of technology in education, such as blended learning, hybrid learning, technology enhanced learning and so on, the term Virtual Learning Environment (VLE) has been the one selected as the title for this study, as it happily sits with the specific focus that will be on using Moodle as an VLE that can embrace different aspects of learning using all available realms of electronic technologies.

Within university's VLE the Moodle platform has really become a particularly popular form of e-learning. The health services are realising they need to change the way that they deliver the training to their staff in order to be able to provide services that have the high quality which result from continuous improvement of the processes of education. When used by hospitals such as the Children's and Mental Health for the Core Mandatory, Role Essential Mandatory, Job Specific and other Continuous Professional Development (CPD) training; Moodle has helped many engaged in such professional development to increase the standard of care by providing healthcare professionals with consistent and progressive training.

Compare to its application within other areas of education, there is a limited available range from which can be selected the best way of implementation e-learning in adult education especially in healthcare sector in hospital environment. Educators in academia and e-learning leads in hospitals first, need to understand the mechanism by which who, what and how of e-learning will be delivered. Therefore, to be able to improve the quality of learning experiences of their students/staff they themselves needed to be acquainted with the epistemological underpinnings of different philosophies and their consequences on the process of training/teaching as an instructional designers [2]. To be able to get effective learning outcome, educators require planning strategies. Many writers (e.g. [3]; [2]) agree that when educators use instructional design properly in their planning strategies, this yields better learning outcomes among students. Although there might be a variety of instructional design models, ADDIE is regarded to be the furthermost communal instructional design model [4]. Putting it briefly, academics or educators or e-learning leads in the organisation - need to set the focus very clearly on the students and staff who will benefit and concentrate on their educational needs, learning preferences, and social interactions by using ADDIE model as an istructioal design.

Amongst a variety of researches regarding an ADDIE model as and instructional design (e.g. [2], [3]), none considered its applicability in the healthcare and adult education. This paper, therefore, provided a guide of useage of the ADDIE Model in the heltcare settings to Design Basic Life Support (BLS) Training for Healthcare Professionals.

\section{Material and Method}

\subsection{Research Design and Method}

This study used the ADDIE Instructional Model Design. ADDIE stands for Analyse, Design, Development, Implementation, and Evaluation as shown in Figure 1. Originally, ADDIE was used as a framework in designing and developing educational and training programs. Yet, in this study it was used as a framework in the development of a Module. The aim of the instructional design was to assist trainers and academic staff to advance their instruction approaches in the existence of suitable resources and approaches. It is a structure of phases for the improvement of education and training strategy in a steady along with trustworthy way. Instructional design is a multifaceted procedure that is inspired, dynamic, and collaborative as stated by Gustafson \& Branch (2007). There is a number of methodical instructional design procedures have been defined (by [5], [6], [7], [8]) in addition to the ADDIE model. But ADDIE model is the better way of designing training involving eLearning courses. 


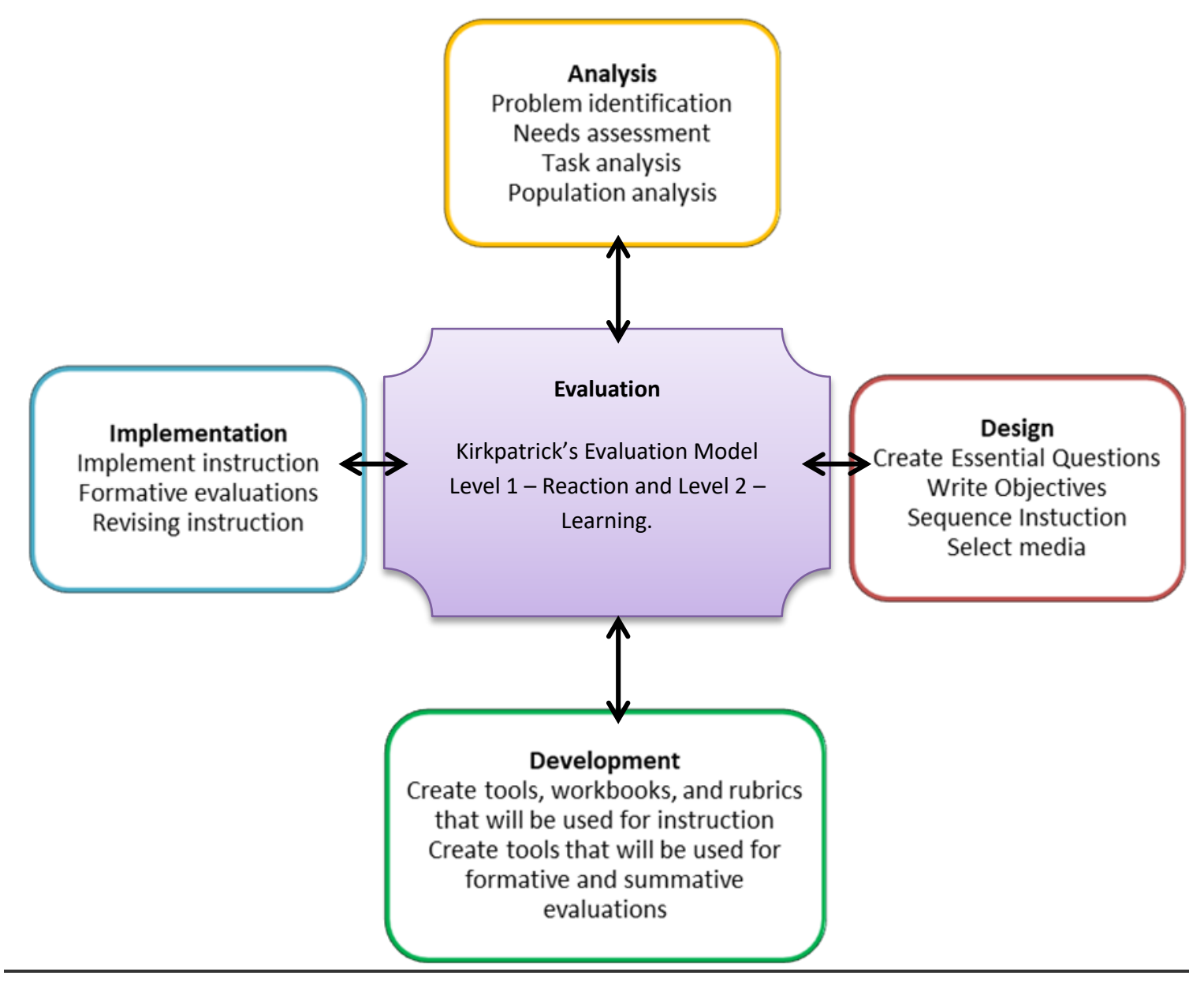

Figure 1- ADDIE Model

The investigator employed the ADDIE model in the improvement of a training module for the Basic Life Support (BLA) training. The reason of using ADDIE instructional systematic model by investigator was that this model would aid educators or trainers to advance the accurateness of their instruction approaches to attain the aims and objectives of the teaching and training. According to the instructional designers, the utilisation of systematically-designed processes might make the teachings and trainings more effectual, well-organised, and appropriate than those designed from less careful and thoughtful development processes ([9]).

In the analysis phase, the current situation/problem needed to be making clear and the need assessment had to be defined. In the designing phase, learning outcomes and objectives had to be clearly defined and also this phase includes delivery methods, structure, duration, assessment and evaluation then storyboard needed to be created. Then, in the development phase, all activities such as media, materials etc. needed to be constructed by considering the first two phases of the model. After that, in the implementation phase, the created training required to be piloted and then it had to be shared with the learner. Lastly, throughout the evaluation phase, the feedback gathering was essential.

In this paper, the BLS training taken as a case study and the training, which was a whole full day, reviewed by the investigator and the subject matter experts (SMES), who provide training, to create a training plan that fit with the requirement of the staff- who, what and how. There were couple of steps in the review of the BLS training. First, the investigator collected and reviews the lessons plan/procedure of the course and prepared a plan including blended learning: face-to-face and eLearning training. Then, the investigator sat with the SMEs and deliberated the training. The investigator provided a copy of the plan to SMEs too. SMEs then passed their comments and responses to the investigator personally or by email. Next, the investigator modified the plan regarding to feedbacks. Consequently, the investigator requested 3 SMEs to evaluate the adaptability and validity of the training.

\subsubsection{Research Participant}

The participants of this study were the thirty (30) staff who already had the BLS training previous year and need to update the training for the 2016. They were conveniently selected by the investigator and SMEs to undergo the try-out to new designed training programme with duration of one (1) hour eLearning as PART 1 and ten (10) minutes face-to-face practical assessment session as PART 2. 


\subsection{Discussion- ADDIE Model Application in the BLS training design in Healthcare and}

Healthcare professionals working in a clinical role need to train with the Basic Life Support (BLS) knowledge and skills that require measuring the need for and delivering basic life support until expert help arrives. BLS comprises of several medical procedures provided to patients with life threatening conditions. All these procedures are concentrated on aiding patients or sustain life till more accurate medical treatment can commence.

The continued enhancement of quality in healthcare services indicates the need to implement systematic training plans for hospital staff. It is consequently essential to establish a training team to guarantee that application of the training does not affect the hospital's provision of healthcare services, bearing in mind the number of staffs to train and the departments to which they belong, the time essential to train the staff on a topic, and the size of the clinical staff working group. Therefore, full BLS face-to-face training were challenging in terms of the clinical staff's time as they need to attend whole day training where it can affect the healthcare services they provide. A best solution for this was the E-learning, that proven to improve both the knowledge and the competence of clinical staff and blending it with face-to-face practical assessment. If an organisation wants to implement VLE (Moodle) and use blended learning successfully, engaging and beneficial to staff, a well-thought-out strategy needs to be planned on Who, What and How.

The model of ADDIE provides benefits to design training to adult learners in a proper and effective way. The author used the ADDIE model not only for its ease application, flexibility and systematic nature but also for its allowance of turning back to previous Phases ([10]). In the Figure, the author demonstrated the way ADDIE model was used in the hospital environment to implement an effective e-learning course. Normally, new training designers have a tendency to skip first two steps and want to jump straight into the third step: 'development', but these designers need to be careful not to skip any steps as each step is critical for effective course design.

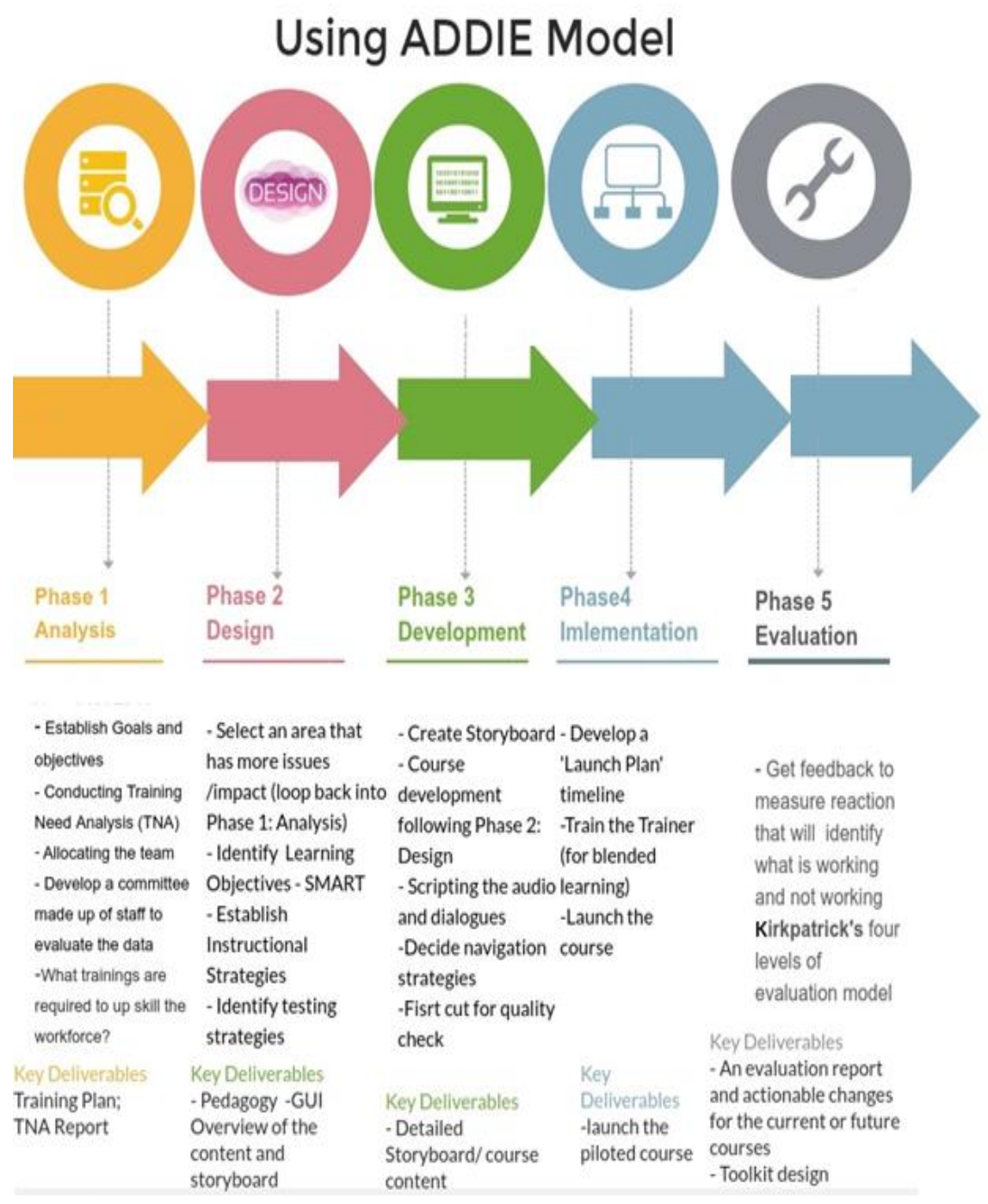

Figure 2. Phases in ADDIE Model to use to design the training content 


\subsubsection{Analysis Phase}

The The analysis phase in an organization is critical as it will help to identify a clear organisation goal and objectives for the Blended Learning process and develop a clear of an understanding of the staff needs, constraints, and existing skills. It is here that trainers/educators identify the learning problem, set goals and objectives. The investigator thinks that without a thorough analysis, the trainers/designers not able to modify the training precisely to the needs of the staffs, and thus can face staffs' negative reaction later in the training run.

In this phase of the study the investigator, focus on three steps.

\subsubsection{Step 1:}

In the first step, the investigator focused on:

\section{- Content and document Analysis}

The blended learning approach used to design the course therefore, the author first identified the parts of the training that needs to be provided as e-learning and the parts which would be more appropriate for face-to-face training. Blended learning is a best way to combine the e-learning and the best aspects of traditional classroom training methods. In the content and document analysis, the investigator differentiated the static (recourses do not require updating) and dynamic (recourses or information require to change time to time such as team contact number or policies etc.) content to be able to identify how modifications of the course will be updated. It might be very annoying for staffs to come across invalid or wrong information in the course resources and this puts them off from completing the training. Also, the investigator had done some content/document analyses and collected data by reviewing the different delivery methods of the BLS training. Then, the investigator considered the trainers' and staff's current situation problems in the staff group analysis.

\section{- Staff Group Analysis}

Identifying staffs' knowledge, need, satisfaction levels and skills is essential to create an effective training. The investigator considered the teachers' and students' current situation problems, aims, objectives, as well as teaching/training and learning setting, except the learners' knowledge. For the staff group's needs and requirements, the following questions are identified:

- What skill deficiencies currently exist?

What are their special needs for learning?

- How does staff perceive the technology use? (staff perceived ease of use and usefulness)

- What is staffs' current knowledge and understanding of the blended learning ?

- What are staffs characteristics such as age, culture etc.?

- What are the training constraints for them? technological, timing and duration etc

Briefly, with the above questions the following criteria are tried to identify from staff:

○ age, education level, physical or learning disabilities, interests to course, experience, personal attitudes to technology or course, study preferences, staffs' motivation, communication skills, staffs' computer skills cooperation skills, experience with different methods and ways of training. previous e-learning experience.

The investigator conducted several interviews with the staff to identify the above questions as well as problems they have encountered during the training and also, staff's opinion about the training times and the content. As a result of this analysis, it was found that staff are struggling to attend the full day training as they have demanding clinical work.

\section{- Objective Analysis}

The investigator prepared very general objectives for the course with the SMEs. While creating the general objectives, the following questions asked to trainers:

- What are the SME's and designers' aims/goals/objectives with regard to the staffs?

- What do the staffs need to learn?

Briefly, the overall objectives of the course need to be identify and also objectives of the individual topics/lessons/activities determined.

\section{- Use of Media Analysis}

The investigator has chosen, by take staff group analysis report into account, the multimedia tools with the SMEs to make sure those multimedia tools that used in the course is suitable with content and these multimedia tools are frequently 
more effective than a presentation of a text. As an example, video of real time clinical procedure will be more effective than showing a picture of procedure or explain the procedure in a text format. Also, graphics, simulations are other multimedia tools that can be use in trainings.

\section{- Organization Culture}

To get some knowledge about the organisation and its culture, the investigator was needed answers to the following questions:

- What is organizational goal for blending learning?

$\circ$ How many staffs will complete the training?

$\circ$ What is the current problem of training?

- What would be the time requirements for the SME(s)?

○ What will be the amount of e-learning training, face-to-face training, and self-study activities (blended learning)?

- What will be the training timetable in regard to number of study hours for staff, or percentage of face-to-face and e-learning training?

Also, learning cultures, existing organizational support, technology tools and infrastructure, training team readiness and learner readiness are identified.

\section{- Training approaches}

The investigator primarily focused on two training philosophies:

- The first one was collaborative learning where staff can collaboratively work together and understand different area of practice and how this will help them implement in their place of work.

$\circ \quad$ The second one was the experiential learning which means learning by practicing/doing. This approach help staffs to gain new knowledge and skills through practical activities.

\subsubsection{Step 2:}

In this step, the author setup a committee for the quality check of the outcomes of each phase before moving on to the next phase.

\subsubsection{Step 3:}

In this last step of Analysis phase the testing the approaches are identified:

$\circ \quad$ Identify the piloting area and training

- Carry out the content analysis with the engagement of stakeholders: SMEs and the staff who already trained for the selected training.

- Document the proposed training solution and instructional strategies

Analysis Phase Outcome: The outcome of this phase:

- Identify goals and objectives and create Blended Learning Strategy document

- Identify the area that has problem to start the piloting

- Training Plan and real timeline of this project

- TNA Report (especially on staff analysis their needs and satisfaction levels)

- Technology recommendation document

- Purposed training solutions and instructional strategies

- Allocate the team (Design/Development/delivery)

Quality: Develop a committee made up of staff to evaluate the data and design.

\subsubsection{Design Phase}

The Design phase is the organised procedure of preparation, classifying and specifying the design of the course/training objectives into steps. The designers/trainers chose an appropriate training approach for each these steps. This phase involves developing detailed storyboard/ prototype.

In this phase, the following planning questions were answered:

- What will staff learn after the completion of training, module or a course? 
- What will staff do to achieve it?

- How can the achieved results be measured?

The identified objectives need to be measurable, so they need to be SMART objectives. For example, the course introduces the basic aspects of life support awareness. It provides staffs with required knowledge and skills such as how to cardio pulmonary resuscitation (CPR) need to be done, and how to safe a child or an adult before the full medical care by the professional. In such cases, the accomplishment of objectives can be measured. Also, the evaluation methods of learnt knowledge and skills and actual assessment are created are designed at this stage. It is important to prepare the tests before the completion of the course content then the focus will be on the achievement of training objectives rather than course content recourses.

Briefly, this phase involves lesson planning, topic content identification, training methodologies, media, learner exercises and assessment criteria. The detailed storyboard/ prototype is developed in this phase.

All the data that gathered during Analysis phase were used leading into the 'Design' phase.

During this phase, the investigator considered the following:

The knowledge level of the staffs is established prior to the start of the training which has been gathered in the design phase.

Based on the time allocated for the training, determine course format and identify delivery methodology, learning modality and materials - e.g. instructor-led + VLE or purely VLE etc.

The structure and sequence (chunking, etc.) of the learning steps to perform the activity from easiest to most difficult are identified. The investigator created the plan of the delivery and the content with the data collected during design phase and involving SMEs. The plan briefly as follows:

- Delivery method of the content was identified. The decision was to have eLearning via VLE as PART 1 to provide all the section via video demonstartion (simulation) and assessing the staff after every video demonstartion and have face-to-face as PART 2 practical assessment session for 10 minutes for staff where 3 SMEs in 30 minutes session provide assessment to 9 staff.

- Staff assessment is developed: there are usually two types of assessments during the course: formative and summative. Formative assessments were self-checks or practice items during the course and summative assessment was at the end of the course to check staff understanding of the training to check their learnt knowledge. The well-designed pre and post quiz designed by utilizing Bloom's Taxonomy informed the staff gained knowledge before and after the training.

- Training evaluation methodology, reporting methods working with SMEs are developed.

- Mini knowledge presentation is conducted to committee that is made up of in the previous phases to validate the training designated to meet learning objectives.

- Implementation and evaluation costs (as require), effort and schedule are reviewed.

Outcome: The outcome of this phase:

- Enhanced content outline or table of content - storyboard/prototype

- Graphic user interface design

\subsubsection{Development}

The 'Development' phase is the actual building of the course/training. All the knowledge and information from pervious phases are shaped into a relevant course for the staff. In this phase of ADDIE model, designers/trainers try to identify and evaluate earlier created resources. If old resources cannot be used, then high-quality resources are prepared by working closely with SME(s). In the development stage creativity is essential. Along with texts, training resources can encompass simulations, video, audio, images and other activities. However, multimedia tools should not be used just because they are simple to generate or find. Almost all sorts of training resources and assessments should be tested and piloted.

The Investigator created the written text resources in a appropriate format as mentioned in the below:

- Extensive scrolling avoided,

- The texts divided into smaller pieces such as bullet points, numbering, levels of headings,

- The less text colours, effects and font types and sizes are used in each slides of the training course;

- Arial as a sans serif is used as commonly easier to read on the screen than other serif fonts;

- Bold or italics is used to highlight text rather than underlining as it slows down staff reading.

- The classroom was designed as a practical session rather than tecahing session

Also, the investigator included the followings in the training course: 
- The SMEs introduced both with text statements and video recordings to introduce the subject and explain the importance of the training in their work practice. This is very effective way to get attention of the staff in the beginning of the course which adds a human touch to the training.

- Welcome page created as this is good way of generating a personal relationship in an e-learning environment. This welcome page motivates staffs. The practical application of knowledge and skills or inform them about training resources.

- The contact details of the SME are provided to staff to communicate with the trainer, if needed.

- Discussion form is set up for the staff to discuss any issues/best practice related with the course.

Outcome: The outcome of this phase:

- Detailed storyboard

- Media files

Draft is prepared in this phase for internal quality check, followed by stakeholder check and feedback.

\subsubsection{Implementation}

Subsequently systematic and careful analysis, designing and development phases, the training must be applied. The 'Implementation' phase is where the developed course is put into action. The course is ready to be delivered to the targeted staff. Even though implementation phase can seem to be the easier phase, it is not. Main activities that held in this phase include:

- Developed a 'Launch Plan' Timeline

- Trained the Trainer (for blended learning)

- $\quad$ Placed the Training Tools/resources on LMS etc.

- Launched the course

In this phase, the BLS training's implantation was primarily employed in the piloting group of staff. First, the investigator identified with the SMEs whose BLS compliance is coming out of date. Then, the investigator sent email to all the staff who needs a training to ask if they would like to get involves in the piloting stage of the BLS training. Around 30 out 50 staff were agreed to involve. The investigator met with the 30 staff to explain the changes and provided and demonstrated the guidance how to access and use the VLE (Moodle) module. Two weeks was given staff to complete the eLearning module on VLE and then in third week they had their 10 minutes assessment session face-to-face.

Outcome: the outcome of this phase:

- Final course design

\subsubsection{Evaluation}

Even though evaluation phase is the last step in the ADDIE model, it takes place through the whole preparation period. After delivery of the training, in the Evaluation phase, in a systematic process, we shall consider feedback from the staff.

The feedback collected during this phase will measure reaction, identify what is working and not working; determine the effectiveness and quality of the delivery. Briefly, it will validate whether the course satisfied its objectives and the effectiveness of the training materials used. Also, this evaluation will help the investigator, trainers, teachers and SMEs to find out any obstacles that may have emerged. Then, by making revisions, adjustments and corrections as needed, ensures the success of the next presentation.

Under Instructional Design,

Purpose got 30 affirmative responses to both questions that asked:

- Is the goal clearly stated?

- Does the training accomplish what was intended?

Objectives received 30, all yes to all four questions when asked about:

- Are the objectives clearly stated?

- Are objectives sequenced in proper order?

- Do objectives cover all parts of the content?

- Are objectives achievable by the staff?

Front End Analysis got 30 yeses out of one question:

- Is the training based on staff needs assessment?

While, Prerequisite Skills/Knowledge received 30 yes to all questions, 
- Is there a prerequisite test of entry level skills in the staff needs analysis?

- Is there a prerequisite test of entry level of knowledge in the staff needs analysis?

Evaluation category that asked about the methods of measuring the staff performance, it 28 yeses and 2 no responses.

Overall Design that talked about the content presentation appropriateness of length, PART 1 videos and assessments, PART 2 practical assessment of 10 minutes, forums on VLE (Moodle), this category received 29 yes responses and 1 no responses.

Statistically, if we use the formula A as an acceptability is equal to number of yes scores (nYes) over total number of yes and no responses (NYes+No) the percentage score of Training Design had $98 \%$ of Acceptability. The score produced out of this evaluation was just way of quantifying of the result of the training evaluation of the BLS and for the clarity of the demonstration of the result.

In the Content category, Content got 29 yes responses and 1 no to seven questions. Content focused on the following questions:

- Does the content meet the stated goal and objective?

- Is the content useable?

- Is the content appropriately sequenced?

- Is the content appropriate for the staff?

- Is the content enough in quantify to cover identified objectives sufficient?

- Is the content accurately correct?

- Is the information repetitive?.

Again, if the result of this questions is to be interpreted using the above mentioned formula, it generated $97 \%$ of acceptability.

Presentation/Physical Aspect has two parts. The first one is Audience and the second one is Physical appeal. Audience part received 30 yes responses to all four questions,

- Is the intended audience specified?

- Is the vocabulary appropriates?

- Is the reading level appropriate?

- Is the content easily readable?

In the Physical Appeal part, out of 1 question, 30 yes response received to the question,

- Does the new BLS design come attractively package?

If data is to be interpreted using the same above mentioned formula, the Presentation or Physical Aspect had $100 \%$ Acceptability.

Table 2. New BLS Design Evaluation

\begin{tabular}{|c|c|c|c|c|c|}
\hline \multirow[b]{2}{*}{ Categories } & \multicolumn{4}{|c|}{ Acceptability } & \multirow{2}{*}{$\begin{array}{c}\text { Acceptability } \\
(A=\text { nYes/nYesNo })\end{array}$} \\
\hline & Yes & No & Uncertain & $\begin{array}{c}\text { Not } \\
\text { applicable }\end{array}$ & \\
\hline Purpose & 30 & 0 & 0 & 0 & $100 \%$ \\
\hline Objectives & 30 & 0 & 0 & 0 & $100 \%$ \\
\hline Front End Analysis & 30 & 0 & 0 & 0 & $100 \%$ \\
\hline Prerequisite Skills/Knowledge & 30 & 0 & 0 & 0 & $100 \%$ \\
\hline \multicolumn{6}{|l|}{ Instructional Design } \\
\hline Content & 28 & 2 & 0 & 0 & $93 \%$ \\
\hline \multicolumn{6}{|l|}{ Presentation/Physical Aspect } \\
\hline Audience & 30 & 0 & 0 & 0 & $100 \%$ \\
\hline Physical Appeal & 30 & 0 & 0 & 0 & $100 \%$ \\
\hline
\end{tabular}

\section{Results}

Results of using ADDIE model to create a training module were successful and the feedback and comments from staff, committee and SMEs was very positive. The organisation has decided to implement ADDIE model to creation of other training modules via especial eLearning training packages to ensure that staff involve the process from the beginning of the design. 
This research applied the ADDIE model for the development of training and teaching which has impact on learning in education, particularly in Basic Life Support training. The ADDIE model was used by other investigators for advancing the teaching and training process in education e.g. multimedia [11], online languages[12], and chest radiography [13].

This study showed that the designing the training by using ADDIE model transformed the role of the instructor from trainercentre method to a staff/people-centred method. The trainer only takes part in small part as a guide and assessor. Hence staff can go an understand the each section of the BLS training content watching the demonstration video as much as they want as some of the staff are shy to ask the trainer to demonstrate the activity again.

\section{Conclusions and Recommendations}

\subsection{Conclusion}

Virtual Learning Environment, Moodle is very effective and beneficial to staff/students, if it is used appropriately. As mentioned earlier, Moodle supplement the traditional training delivery, face-to-face, as it assists in administration by providing space for observing/monitoring the staff records, make certification/documentation of staff profiles controllable, support tracking of staff progression and simplify delivery of training programs. Though, while designing new training course on the Moodle system in healthcare even in universities, it is needed to tread with carefulness and select the delivery methods of the training, if the required infrastructure and other resources are not consistently available. Also, the systematic process, such as ADDIE model, needs to be used for creating more effective and engaging courses.

In view of the foregoing findings, the following conclusions were drawn:

As it was observed in this study, the design and development of the Module used the ADDIE Model. In short, the process of Analysis, Design, Development, Implementation, and Evaluation was observed in creation of the Module.

One of the findings of this study showed that a significant difference was observed after the participants were immersed in the developed Module. This is an indication that the process and procedure in the design and development of the learning Module in BLS was followed accordingly.

It simply tells that in the development of Module it is important to analyse the context: the learners, learning environment and other factors relating to the recipients. Next thing to consider is the planning of the process and content of the Module. Also, Module production should undergo the process of validation to determine its physical and content validity. In addition to this validation from the experts, it should also undergo a validation from the recipient through pilot testing. Finally, evaluation should serve as the general evaluation of the process and product of the study.

The process mentioned is just an example of the design that this study utilized. This reveals that any instructional model design process or procedure, if it is followed carefully, it will yield a positive result.

The development of Module is not easy and simple. It needs a careful study or research in order to achieve the desired outcome. The processes and procedures should be meticulously observed and be based on historical and/or psychological backgrounds of the eventual users who will benefit from the Module. In doing so, the users will see that the Module or any instructional material designed and developed for them is significant in their learning experience as they can relate to the lessons and activities that have been contextualized and localized for them.

Both staff and SMEs/trainers respondents of this study recognized that a staff- centred learning environment, individualized instruction, through a module, and the use of technology can be a great help in the learning and teaching experience.

\subsection{Recommendation}

ADDIE is one of the models of designing training courses that is simple to follow. It offers a flexibility that is crucial in elearning course development. The resercaher believes there is not anything to be criticised, it is its advantage. Being systematic prevents pointless mistakes during designing the training course. ADDIE is a iterative process and the author uses this model as an iterative process where it is easy to come back to previous phase of the model to validate the design work. The first 'Analysis phase' is the most important phase. Some designers/trainers think analysis phase is very time-consuming. However, when the long term considers actually it saves money and time because when an appropriate training tool is used and implemented into a course, the result is a satisfactory course where completions of the training is increased. The investigator uses the ADDIE model in a healthcare environment as a useful experimental framework for designing e-learning and blended training courses on Moodle. ADDIE is a tool to follow in order to create very effective training courses on the Moodle. Therefore, the investigator suggests other trainers and designers to ADDIE model to create very engaging and effective training courses or programme.

\section{Acknowledge}

This research and implementation of blended learning approach will not be able to completed without SMEs and the staff who involved this study. 


\section{References}

[1] R. Rahmany, B. Sadeghi, and A. Chegini. (2014), “Normalization of CALL and TPACK: Discovering teachers' opportunities and challenges" [Online].

Available: http://citeseerx.ist.psu.edu/viewdoc/download?doi=10.1.1.657.3445\&rep=rep1\&type=pdf\#page=171

[2] B. Bandhana, "Designing Instructional Design: Emerging Issues" Vol 1, No 3, 2010 [Online]. Available: https://www.iiste.org/Journals/index.php/JEP/article/view/1656

[3] E. Syatriana, D. Husain and B. Jabu, "A Model of Creating Instructional Materials Based on the School Curriculum for Indonesian Secondary Schools" Vol 4, No 20, 2013 [Online]. Available: https://www.academia.edu/4655577/A_Model_of_Creating_Instructional_Materials_Based_on the_School_Curriculum_for_In donesian_Secondary_Schools

[4] I. Shibley,K.E. Amaral,J.D. Shank, and L.R. Shibley, "E-signing a Blended Course: Using ADDIE to Guide Instructional Design," Journal of College Science Teaching, vol. 40, pp. 80-85, Jul. 2011.

[5] W. Dick, L. CareL, The systematic design of instruction, 4th ed., New York: Harper Collins College Publishers, 1996.

[6] R.M. Gagne, L.J. Briggs, \& W.W. Wager, Principles of Instructional Design, 4th ed., Orlando: Harcourt Brace Jovanovich, 1992.

[7] J.E. Kemp, G.R. Morrison, and S.M. Ross, Designing effective instruction, 2nd ed., Upper Saddle River, NJ: Prentice Hall, 1998.

[8] P.L. Smith \& T.L. Ragan, Instructional design, 2nd ed., New York: Merrill. States of matter animation. (Harcourt school publishers), 1998.

[9] K.L. Gustafson \& R.M. Branch, What is instructional design? In Reiser, R, A. and Dempsey, J. V. (Eds) Trends and issues in instructional design and technology, 2nd ed. (pp. 11-28), Upper Saddle River, N.J.: Pearson/Merrill Prentice Hall, 2007.

[10] J. Vejvodová, "The ADDIE Model: Dead or Alive?" 2009 [Online]. Available: http://virtuni.eas.sk/rocnik/2009/pdf/paper_127.pdf

[11] S. Arkun \& B. Akkoyunlu, "A Study on the Development Process of a Multimedia Learning Environment according to the ADDIE Model and Student's Opinions of the Multimedia Learning Environment," Interactive Educational Multimedia, vol. 17, pp. 1-19, 2008.

[12] J. Colpaert, "Pedagogy-Driven Design for Online Language Teaching and Learning," CALICO Journal, vol. 23, pp. 477-497, May 2006. [Online]. Available: https://eric.ed.gov/?id=EJ835476

[13] L. Cheung1, "Using the ADDIE Model of Instructional Design to Teach Chest Radiograph Interpretation," Journal of Biomedical Education, vol. 2016, June 2006. [Online]. Available: https://www.hindawi.com/journals/jbe/2016/9502572/ 